Document downloaded from:

http://hdl.handle.net/10251/69756

This paper must be cited as:

Martínez, C.; Azagra Caro, JM.; Maraut, S. (2013). Academic Inventors, Scientific Impact and the Institutionalisation of Pasteur's Quadrant in Spain. Industry and Innovation. 20(5):438-455. doi:10.1080/13662716.2013.824194.

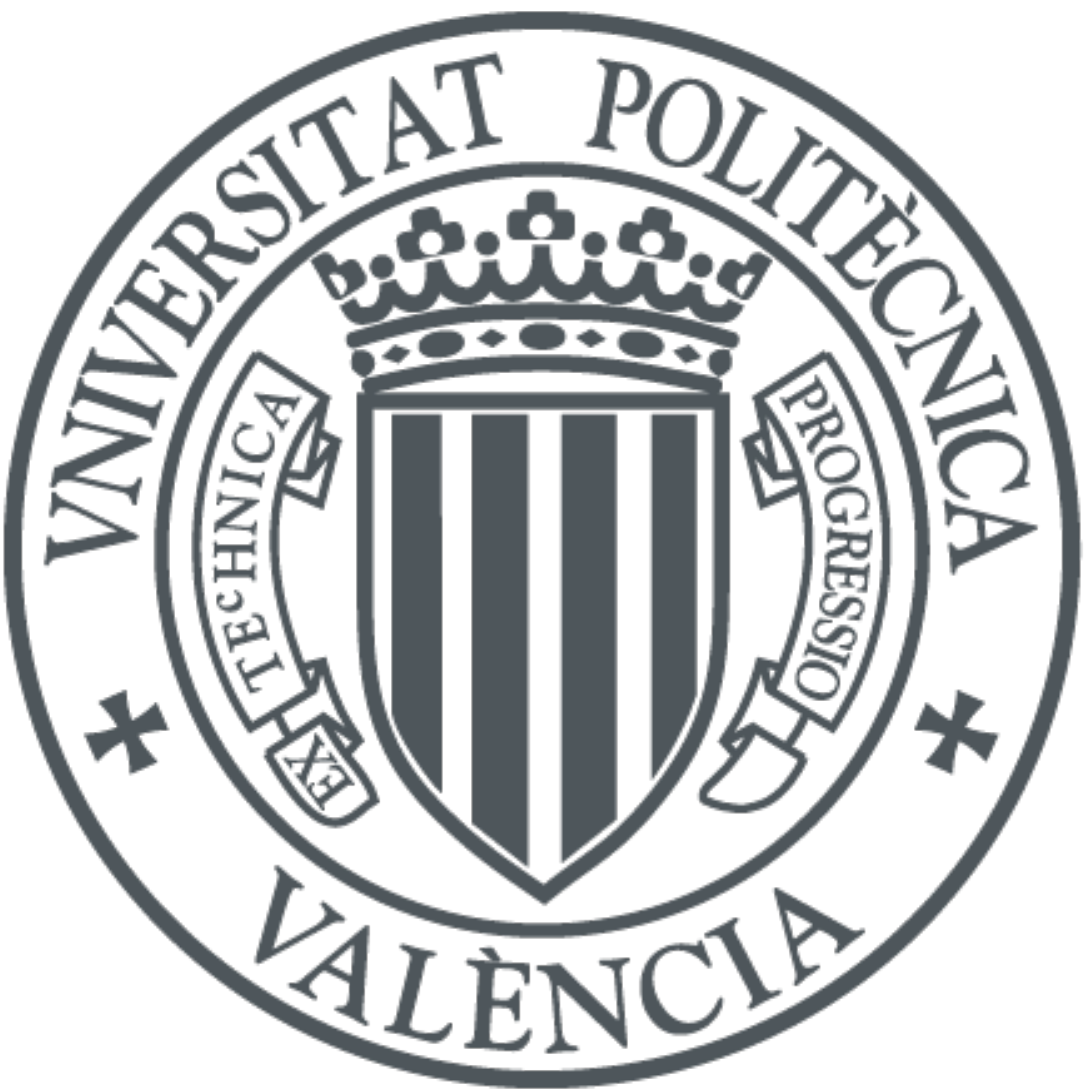

The final publication is available at

http://dx.doi.org/10.1080/13662716.2013.824194

Copyright Taylor \& Francis (Routledge)

Additional Information 


\title{
ACADEMIC INVENTORS, SCIENTIFIC IMPACT AND THE INSTITUTIONALISATION OF PASTEUR'S QUADRANT
}

\author{
IN SPAIN \\ CATALINA MARTIINEZ ${ }^{1, *}$, JOAQUÍN M. AZAGRA-CARO ${ }^{* *}$, STÉPHANE MARAUT** \\ * CSIC - Institute of Public Goods and Policies, Albasanz, 26-28, E-28037 Madrid, Spain, \\ ** INGENIO (CSIC-UPV), Universitat Politècnica de València, Camino de Vera s/n, E-46022 Valencia, \\ Spain, *** Independent researcher, Madrid, Spain
}

\begin{abstract}
We rely on a novel database of Spanish author-inventors to explore the relationship between the past patenting experience of academic authors and the scientific impact (citations received and journal prestige) of scientific articles published during 20032008 in journals listed in SCOPUS. We also study how such a relationship is affected by differences across academic affiliations, distinguishing between public universities and different types of non-university public research organisations. Our econometric estimations show that scientific impact is positively associated with having authors with past patenting experience as inventors at the European Patent Office. Exceptions are the articles of authors affiliated to new independent public research centres, not tied to the civil service model and oriented to do research that is both excellent and use-inspired. These are also on average the most cited articles.
\end{abstract}

KEY WORDS: Scientific impact, articles, patents, academic inventors.

\footnotetext{
${ }^{1}$ Correspondence Address: Institute of Public Goods and Policies (CSIC-IPP), Albasanz, 26-28, E-28037 Madrid, Spain. E-mail: catalina.martinez@csic.es
} 


\section{Introduction}

Researchers at public institutions are increasingly encouraged to produce research that is socio-economically relevant, useful to industry and preferably patentable, but reputation, incentive schemes and professional career progression are chiefly related to scientific excellence, measured in terms of peer recognition. Although there may be a potential conflict between both objectives, they tend to go hand in hand in policy agendas. Public support increasingly gives priority to research that has scientific impact and is use-inspired as in Pasteur's Quadrant (Stokes, 1997). On the other hand, academic inventors are a rare species, who by definition have experience in producing use-inspired research leading to patents. Patenting is increasingly promoted within academic institutions, as evidenced by their rising patent numbers (OECD, 2011a).

The aim of this paper is to explore the relationship between scientific impact and the patenting experience of academic authors, and to analyse how it is affected by differences across academic affiliations and with regard to patent ownership (academic or not).

We focus on Spain, a country which in aggregate terms ranks high in terms of the number of academic publications, but relatively low in terms of scientific impact and patent numbers. It is also a country where, as elsewhere, public research institutions are under increasing funding and accountability pressures (Sanz-Menendez and CruzCastro, 2003).

The Spanish public research organisational field has gone through important changes in the past few decades following the emergence of new legitimation models (CruzCastro and Sanz-Menendez, 2007a). A new type of independent public research centres has emerged since the late 1990s, characterised by more flexible institutional arrangements and oriented, by design, to do research that is both excellent and use- 
inspired (Cruz-Castro et al., 2012). We give special attention to these new centres in our analysis, distinguishing them from other types of Public Research Organisations (PROs).

There are numerous economic studies on whether patenting and publishing are substitutes or complements and whether patenting potentially reduces the impact and changes the direction of academic research. They tend to conclude that patenting and publishing are compatible. Generally, academic inventors are more productive and tend to receive more citations than their peers (Agrawal and Henderson, 2002; van Looy et al., 2006a; Azagra-Caro et al., 2007; Breschi et al., 2008; Azoulay et al., 2009). However, most existing economic work focuses on aggregates of publications of individual researchers, which may hide the contribution of academic inventors to individual publications, and their interaction with other determinants of scientific impact at an article level. Only a few studies have examined the influence of patent ownership, academic or not, on the scientific production of academic inventors (Fabrizio and Di Minin, 2008; Czarnitzki et al., 2009). The majority focus on universities (van Looy et al., 2006a; Azagra-Caro et al., 2007; Breschi et al., 2008; Fabrizio and Di Minin, 2008; Baldini, 2009; Wong and Singh, 2010; Mejer, 2011), and a few on specific PROs (Buenstorf, 2009; Azagra-Caro, 2011). The evidence on differences between universities and non-university PROs is very scarce (Lissoni et al., 2013), and to our knowledge there are no studies on academic patenting that distinguish between different types of non-university PROs.

Our aim is to address these issues by exploiting a novel database which is the result of matching all Spanish authors of SCOPUS articles published between 2003 and 2008 with all Spanish inventors of patents filed at the European Patent Office (EPO) between 1978 and 2009 (Maraut and Martínez, 2013). 
The paper is organised as follows. The next section provides a literature review on scientific impact and academic patenting. Section 3 presents some background on Spain and Section 4 describes our data. Section 5 presents descriptive results and Section 6 the econometric results. Section 7 concludes.

\section{Academic patenting and scientific impact}

Only a few academic researchers have patenting experience, but academic inventors tend to be overrepresented amongst the most productive ones: better scientists are more likely to patent and publish more (Stephan et al., 2007; Fabrizio and Di Minin, 2008; Azoulay et al., 2009). There is also ample evidence of a positive association between academic patenting and scientific impact, but whether it is because of patenting or due to some confounding factors that determine both scientific impact and patenting activity remains a subject for research. Not all the heterogeneity of researchers is reflected in observables; some explanatory variables affecting differences in both inventive activities and research performance remain unobservable, such as individual skills, effort and serendipity (Buenstorf, 2009). Previous studies have identified past scientific productivity and visibility, network connections, patenting volume, institutional context, patent ownership and research on Pasteur's Quadrant (where dual disclosure through patents and publications is possible) as having a positive influence on the scientific impact of academic inventors’ publications.

According to Breschi et al. (2008), academic patenting may strengthen the Matthew effect, whereby more productive scientists enjoy increasing returns to reputation and visibility over time. Forti et al. (2013) find that inventors' networks are larger, more connected and more complex than those of their colleagues who never filed a patent, consistently with Meyer (2006). Agrawal and Henderson (2002) argue that researchers 
who patent extensively may be more highly cited by industry.

Fabrizio and Di Minin (2008) find a positive relationship between patenting and citations received, except for researchers who patent more frequently. The positive association is consistent with other studies, but the negative effect of patent intensity was not found in studies at MIT (Agrawal and Henderson, 2002) and Stanford (Goldfarb et al., 2009), suggesting that elite institutions, where access to funding is less of a problem, may be different to the average faculty.

Research content also matters. In the theoretical framework developed by Gans et al. (2011), patenting and publishing are complementary outputs from projects generating dual knowledge, as in Pasteur's Quadrant. The authors identify four possible disclosure regimes: patenting, publishing, secrecy and patent-paper pairs, with the latter being widely used in science-based industries and increasingly among academic scientists. Murray and Stern (2007) find that papers in patent-paper pairs are more cited than other articles at similar risk but not associated with patents. ${ }^{2}$ Furthermore Azoulay et al. (2009) find that the effect of patenting outlasts the initial idea leading to the patent, as it enables scientists to continue sourcing ideas and funds from industry over time.

Nonetheless, not all researchers are equally capable of doing research in Pasteur's Quadrant. The costs and opportunities for combining academic research and industrial applications may also largely depend on the specific topic of specialisation and individual research trajectories, where path dependency is an important factor to take into account. Calderini et al. (2007) find that the probability to patent is a positive function of productivity, basicness or impact for low-to-moderate-high values of publication-related indicators, but a negative function for high values.

\footnotetext{
${ }^{2}$ They also find that the article citation rate of papers in patent-paper pairs weakly declines after the patent in the pair is granted.
} 
Several studies find that the positive correlation between patenting and scientific productivity of scientists does not hold when patents are owned by business (Fabrizio and Di Minin, 2005; Breschi et al., 2008; Czarnitzki et al., 2009; Mejer, 2011). Retaining ownership of an academic-invented patent is a significant hurdle and academic institutions may not pursue a patent unless they have identified a licensee (Goldfarb et al., 2009), especially when the cost of patenting is high, but this may change over time as the institutional attitude changes towards patents. On the other hand, academic research leading to a business patent may be less closely related to fundamental research (Fabrizio and Di Minin, 2008), but may be complementary to it due to spillovers (Jensen et al., 2011).

Taking the institutional context into account enables factors to be considered that may increase the propensity of researchers to be involved in patenting, such as positive attitudes toward commercialisation, higher royalty shares, or the presence of prominent peers engaged in patenting, and the commercialisation and availability of additional resources (e.g. Azoulay et al., 2009). Also, increased incentives for technology transfer may lead scientists to work on more productive or complementary research areas (Goldfarb et al., 2009).

Based on all these works, on average we would expect scientific impact to be positively associated with the presence of inventors among authors insofar as inventors are likely to be more productive (Matthew effect) and tend to have larger networks than non-inventors. We would also expect this association to be more salient for articles in scientific areas where dual disclosure is possible. The mechanisms underlying these positive correlations are however complex and largely depend on personal, field and institutional characteristics. For instance, the expected effect of the intensity of past patenting experience (number of patents) is not clear and may largely depend on the 
institutions to which the author-inventors are affiliated, research trajectories and topic of specialisation. Academic inventors who patent more intensively would have access to more resources, but may have also diverted more time from research to patenting and publish articles that have a lower impact in the scientific community. The net effect would depend on institutional support to patenting and general attitudes to commercialisation, in addition to whether the research field they are specialised in is more or less prone to derive results in Pasteur's Quadrant. Finally, we would expect articles with author-inventors who only have business-owned patents to be less cited because they may do research in more applied fields, where it is more difficult to find spillovers from consulting to basic research.

\section{Background: Spanish public research institutions}

PROs are a heterogeneous group of research performing centres that benefit from high shares of public funding (Sanz-Menendez and Cruz-Castro, 2003; OECD, 2011b). The literature on academic patenting tends to focus on universities and a particular type of PROs: overarching multidisciplinary PROs, such as the National Centre for Scientific Research (CNRS) in France, the National Research Council (CNR) in Italy, the Spanish National Research Council (CSIC) in Spain and the Max Planck Society (MPG) in Germany. They provide a starting point for analysis since, in most European countries these are the top patenting academic institutions (Cesaroni and Piccaluga, 2005; Potì and Reale, 2005; Azagra-Caro et al., 2007; Bach and Llerena, 2007; Moutinho et al., 2007; Buenstorf, 2009). Other types of PROs have not been studied in the literature on academic patenting. We will refer to them hereafter as traditional mission-oriented

public research centres (MOCs) and newly created independent public research 
institutes (IRIs). ${ }^{3}$ MOCs are specialised in particular fields, such as agriculture, health, defence and energy, and depend on the corresponding government departments responsible for those fields. IRIs are a new type of research centre that is being promoted by governments and research funding agencies in many OECD countries, but little attention has been paid to them so far in the international literature. The IRI model is characterised by strong cooperation with the private sector, independent legal status, and by performing research that aims to be both excellent and relevant to society (CruzCastro et al., 2012). ${ }^{4}$

The distinction between different types of PROs deserves some attention. Spanish public universities are autonomous entities, which depend legally and financially on regional governments, teaching is an important mission and growth depends on the demand for teaching (Mora, 2001). In contrast, non-university PROs tend to grow based on the demand for research. Furthermore, the involvement of most European universities in patenting activity is relatively recent, whereas other large PROs have long-standing traditions of an industry orientation and patenting.

Among the non-university PROs, CSIC stands out as the largest Spanish PRO, organised as an umbrella organisation comprising more than one hundred centres. ${ }^{5}$ The Spanish MOCs include the longest established centres, created before the 1980s, focused on solving problems related to the sectors governed by their ministries, at

\footnotetext{
${ }^{3}$ This terminology follows the classification presented in OECD (2011b) and is consistent with that used in Arnold et al. (2010), distinguishing between scientific research institutes and government laboratories.

${ }^{4}$ This type of institutes may be known in other countries as "centers of excellence” or "multidisciplinary research centers” (OECD, 2011b; Bozeman and Boardman, 2003).

${ }^{5}$ www.csic.es
} 
national or regional government levels. ${ }^{6}$ Tenured researchers at universities, CSIC and MOCs are civil servants, but the share of non-tenured researchers can be high and varies across institutions (Sanz-Menendez and Cruz-Castro, 2011). ${ }^{7}$ All researchers working at IRIs are hired with private labour law contracts, contract continuation depends on evaluation results and there is a high turnover of staff. The Spanish IRIs have been established since the end of the 1990s following public initiatives at national and regional levels with the aim of organising public research with more flexible institutional arrangements. They have independent legal status as not-for-profit foundations and are all resourced by public and private funds (Cruz-Castro et al., 2012). The regional government of Catalonia has been the most active in promoting the IRI model. $^{8}$

The Spanish regulatory framework for the ownership of inventions is the same for all employees, regardless of their sector of employment - inventions belong to employers, as stated in the Spanish Patent Law of 1986 (Blanco, 1999). ${ }^{9}$ At the end of the 1980s,

\footnotetext{
${ }^{6}$ E.g. CIEMAT, Instituto de Salud Carlos III, INIA, IGME, INTA, CIMA.

${ }^{7}$ The average share of tenured researchers and professors in public universities with respect to the total was $47 \%$ in the academic year 2010/11. For some universities, it was above $70 \%$ (Polytechnic University of Madrid), and for others was around 20\% (University Pompeu Fabra). Source: http://www.mecd.gob.es

${ }^{8}$ For a description of the Catalan IRI model and a list of centres, see http://cerca.cat/en/generalcharacteristics/.

${ }^{9}$ In the case of contract research or consulting projects developed by public researchers but funded by firms, the title of the patents can be de facto retained by the contractor. This can happen either as a result of negotiations between the contractor and the administration of the public institution or because the research was the result of consulting work carried out by the researcher without the knowledge of its institution. Maraut and Martinez (2013) show that the share of academic inventions that are business owned differ across institutions and it is lower for CSIC than for universities.
} 
universities and public research centres began to promote technology transfer actively, starting with CSIC which created the first Technology Transfer Office (TTO) in 1985 (Garcia and Sanz-Menendez, 2003).

As regards performance evaluation criteria, during the 1980s, the priority was to improve the scientific base in the public sector, especially in universities, but starting in the 1990s, there was a move from block grant funding to project funding (Cruz-Castro et al., 2012). Moreover, a system of performance evaluation of public researchers' individual research was introduced at the end of the 1980s, the so-called sexenios (SanzMenendez, 1995; Cruz-Castro and Sanz-Menendez, 2007b). These incentives, although financially modest, have reputational value and a positive influence on access to resources and professional career advancement. Scientific impact has been explicitly introduced into evaluation criteria since the late 1990s, by explicitly giving more importance to publications in high impact journals (Osuna et al., 2011). Patents have been one of the items taken into account since 1994. In 2005, a change was introduced in the criteria, prioritising international patents (EPO or PCT) over patents filed only at the Spanish Patent and Trademark Office (OEPM).

Thus, Spanish civil servant researchers are increasingly subject to performance evaluations based on the scientific impact of their publications, with patenting activity gaining weight as an additional evaluation criterion. In this context, the IRIs were set up with the aim of optimising the conditions leading to both academic excellence and socio-economic relevance (Cruz-Castro et al., 2012). They are not bound by civil service employment rules or by state-level regulations on research performance evaluations that affect individual researchers in other PROs. ${ }^{10}$

\footnotetext{
${ }^{10}$ Some extracts from the mission statements of Spanish IRIs are included as Supplementary Material.
} 


\section{Data}

Our unit of observation is the academic article. We consider all academic articles published by Spanish authors in 2003-2008 in journals listed in SCOPUS, excluding those classified in scientific fields that are non-technologically related (e.g. arts and humanities; business, management and accounting; economics, econometrics and finance; psychology; social sciences). ${ }^{11}$ We limit our sample to academic articles by discarding articles without Spanish academic authors based on the SCImago Group normalisation of SCOPUS Spanish author affiliations (SCImago, 2011), which we also use to distinguish across types of Spanish academic affiliations (universities, CSIC, MOCs and IRIs) and build 322 dummies, each corresponding to a different academic affiliation.

Two different measures of the scientific impact of articles are used: i) citations received up to December 2009; and ii) prestige of the journal where the article is published, as measured by the SCImago Journal Rank (SJR) (González-Pereira et al., 2010). ${ }^{12}$ The raw number of citations received by a given article is an indication of the impact of an article in the scientific community. The prestige of the journal where it is published is a measure of its expected scientific influence and visibility, as it accounts

\footnotetext{
${ }^{11}$ A journal may be classified by SCOPUS in more than one field. For instance, $43 \%$ of all articles in our database classified in the field 'Biochemistry, Genetics and Molecular Biology' have it as their only field, but $17 \%$ are also classified in 'Medicine' and 9\% in 'Chemistry'.

12 The SJR is calculated based on citations to articles published in a given journal in the previous 3 years, correcting for accumulated prestige and size of the journal (http://www.scimagojr.com/). It takes positive continuous values, with the maximum being in the range of $10-20$, but the values themselves only make sense in the context of comparisons among journals, "they are just a way to put journals in order" (http://www.journalmetrics.com/faq.php)
} 
for both the aggregate number of citations received by a journal and the importance or prestige of the journals from where such citations come. ${ }^{13}$ Institutions, policy makers and scientists increasingly consider both.

Other article-related variables from SCOPUS are publication year, scientific field, number of authors and foreign authors, in line with previous econometric studies on citations to scientific papers (see, e.g., Frenken et al., 2005; Fok and Franses, 2007; Stremersch et al., 2007; Haslam et al., 2008; Mingers and Xu, 2010).

For the identification of articles with academic authors having past patenting experience, we draw from the results of matching Spanish authors of SCOPUS publications to Spanish inventors of EPO applications from PATSTAT September 2010, as described in Maraut and Martinez (2013). ${ }^{14}$

We consider that an article is written by academic inventors if at least one of its academic authors is listed as inventor in EPO patents filed before (up to 25 years) or on the article's publication year. If an article is published before the filing date of all EPO patents invented by its authors, we consider it as not having academic inventors in the authorship. Our sample thus includes active authors with past patenting activity, who might have started their academic career long before the publication period we are studying (2003-2008), but it excludes academics who might also have patented many years ago but do not publish anymore. ${ }^{15}$

We categorise patents by their institutional ownership, based on the Eurostat/KUL methodology (van Looy et al., 2006b).

\footnotetext{
${ }^{13}$ http://www.journalmetrics.com/faq.php

${ }^{14}$ A summary of the matching methodology is available as supplementary material.

${ }^{15}$ Life-cycle aging effects lead researchers to be, in general, more productive during the early stages of their academic career (Levin and Stephan, 1991).
} 
Additional variables include the following. First, a measure of the visibility of Spanish authors calculated as the average number of citations to articles published in t-1 received by the authors of an article published in $t,{ }^{16}$ which we break down into visibility of Spanish authors who are not academic inventors and visibility of Spanish academic inventors. ${ }^{17}$ Second, a count of all the patents invented by the academic inventors in the article, distinguishing between two types: those owned or co-owned by academic institutions and those owned by other institutions, mainly business. Third, the number of years since the first patent of the academic inventors in the article was filed.

Our database does not include information on the personal characteristics of academic authors that might influence scientific impact, such as age, seniority or full publication records for authors. Other determinants at an article level, such as its real quality, are unobservable. We are aware of these limitations and refrain from inferring any causality conclusion from our results. Our study should therefore be considered as exploratory, pointing at significant statistical associations between scientific impact and available observables.

Finally, it should be noted that our sample consists only of articles published by Spanish researchers in SCOPUS listed journals. Despite the large coverage of SCOPUS, with around 20,000 peer-reviewed journals, ${ }^{18}$ academic results may also be published

\footnotetext{
${ }^{16}$ We use the author identifier available in SCOPUS to link articles in $\mathrm{t}$ with articles in $\mathrm{t}-1$ by the same author. Our visibility measure is equal to zero either when the authors of a given article have no articles published in the previous year or when their previous year's publications have not received any citation.

17 The one year lag is in line with Jensen et al. (2011), who use the number of publications and the total number of citations received by faculty in the previous year as 'proxies of faculty quality'. Since we only have publications of Spanish authors between 2003 and 2008, taking one year lag to build a measure of visibility enables us to keep articles with publication years 2004-2008 for the analysis.

${ }^{18}$ http://www.info.sciverse.com/scopus/scopus-in-detail/facts/
} 
elsewhere. On the other hand, not all academic invented patents are filed at EPO - we would probably find more articles written by Spanish academic inventors if we had also included patents filed in Spain and also considered articles not listed in SCOPUS. However, institutional incentive schemes give priority to international peer-reviewed journals and international patents. Thus, our sample includes those academic inventors who are potentially affected by these schemes.

\section{Descriptive results}

Descriptive statistics for the samples used in the econometric analysis can be found in Table $1 .{ }^{19}$ In the full sample of 132,337 Spanish academic articles, $40 \%$ have foreign authors and 13\% have Spanish academic inventors amongst the authors. The number of articles with academic inventors has more than doubled between 2003 and 2008 (from 1,853 to 3,937 in 2008), experiencing a higher growth than articles without academic inventors (from 15,231 to 23,681). The share of articles with foreign authors is lower (35\%) in the subsample of 17,452 academic articles with academic inventors. ${ }^{20}$

Two observations reflect the longer patenting tradition of CSIC researchers and the use-inspired research orientation of IRIs, as well as the fact that IRIs have been created more recently than other PROs. First, CSIC and IRIs are relatively more represented than universities and MOCs in the subsample of articles with academic inventors than in

\footnotetext{
${ }^{19}$ Additional tables with descriptive statistics for other relevant samples are included as Supplementary Material.

${ }^{20}$ This can be related to the nature of the research they carry out, which may require larger research teams working in the same laboratories, or to their ability to establish larger research groups at their own institutions probably because they have access to more resources.
} 
the full sample (39\% and 10\% of all articles with academic inventors involve CSIC and IRI authors in the subsample, respectively, compared to $23 \%$ and $6 \%$ in the full sample). Second, academic inventors in articles with IRI and CSIC authors have more patents not owned by academic institutions (3.3 and 2.2 respectively) than academic inventors in articles with university or MOC authors (1.5 and 0.7 respectively). Academic inventors in articles with CSIC authors are the ones with the largest patent stock (6.2 patents on average), followed by those in articles with IRI authors (4.2). The large number of not academic owned patents for articles with CSIC and IRI articles is consistent with the existence of spillovers and complementarity between basic research and consulting suggested by Jensen et al. (2011), and the largest patent volume in CSIC would be related to its largest patenting tradition and possibly research specialisation of productive CSIC institutes in patentable areas, such as chemistry (Azagra-Caro, 2011).

\{Table 1 around here $\}$

Turning to scientific impact indicators, we observe that articles with academic inventors are more cited and published in journals ranked higher than the average article. As shown in Table 2, articles with academic inventors, from all kinds of institutions, are on average published in higher ranked journals than articles without. The difference is also positive and significant for the average number of citations, except for articles with IRI authors, which are also the most highly cited with or without academic inventors, followed by articles with CSIC authors.

\{Table 2 around here $\}$

Figure 1 displays scientific field differences in the distribution of articles (bars: left vertical axis) and mean differences in citations received with respect to the annual average (lines: right vertical axis) for the first three samples described in Table 1 . The top fields for all academic articles are chemistry (18\%), biology (17\%), biochemistry 
(16\%), medicine (15\%) and physics (13\%). Articles with academic inventors are more concentrated than average in biochemistry (26\%) and chemistry (28\%). This is consistent with the academic patenting literature where many studies have focused on biotechnology research for being an area of burgeoning business development where technological advances are science-based (e.g. Murray and Stern, 2007). But, as stressed by Stokes (1997), research that is both for understanding and use-inspired, is not constrained to specific scientific fields, with historical examples found in very diverse areas, from biotechnology to physics. Top fields for articles with IRI authors are medicine (30\%), biochemistry (29\%), physics (18\%) and chemistry (12\%). Many IRIs are specialised in health and life sciences, but they aim to combine research from different disciplines with a problem-solving approach. As stated by the directors of a Basque IRI: "In the 21st century the convergence between life and chemical sciences with the physical sciences, mathematics and engineering will foster an economic growth comparable to that driven by the convergence between the physical sciences and engineering in the 20th century."21

Finally, the information regarding citation mean differences across fields with respect to the annual average for the different samples, also displayed in Figure 1, indicates that articles with academic inventors consistently receive more citations than the average academic article, and except in the two fields where they are less represented (energy and chemical engineering), articles with IRI authors always receive more citations than the average academic article. ${ }^{22}$

\{Figure 1 around here\}

\footnotetext{
${ }^{21}$ http://www.cicbiogune.es/uploads/doc/quienes_somos/BioSpain2012.pdf

${ }^{22}$ A similar figure for journal rank is provided as Supplementary Material.
} 


\section{Econometric results}

Given the nature of our first dependent variable, i.e. number of citations, which can take only non-negative integer values and is characterised by a skewed distribution, we choose count data estimation techniques, being negative binomial regression, as the preferred model. We use ordinary least squares for our second set of regressions using journal rank as the dependent variable, as it takes continuous positive values. ${ }^{23} \mathrm{We}$ include dummies for scientific fields, institutional affiliations of academic authors and publication years in all regressions.

We first estimate the effect of having academic inventors among the authors on our two dependent variables for the full sample of all academic articles (Table 3). Results are in line with the findings of previous studies. Articles with academic inventors receive more citations and are published in higher ranked journals than articles without academic inventors (regressions 1 and 5). Their effect on citations and journal rank is very similar if we condition as well on the visibility of authors who are not academic inventors (regressions 2 and 6). ${ }^{24}$

To test if such a positive association also holds when focusing on different types of academic authors' affiliations, we break down the full sample into articles with and without academic authors of each institutional type: public universities, CSIC, MOCs

\footnotetext{
${ }^{23}$ Scientific fields, publication year and authors' institution dummies are jointly significant according to Wald tests in all regressions. Likelihood ratio tests that negative binomial outperforms Poisson models and Vuong statistic shows indifference of zero-inflated negative binomial and binomial regression for the estimation of the number of citations.

${ }^{24}$ The marginal effect of the academic inventor dummy diminishes substantially when we include total visibility of Spanish authors, rather than the visibility of Spanish authors who are not academic inventors, indicating that a large share of the academic inventor's effect can be attributed to their visibility.
} 
and IRIs. The positive and significant coefficient of the academic inventor dummy is maintained for all institution types, except for articles with IRI authors (regressions 4 and 8) and the effect without IRI authors is similar to that in the full sample (regressions 3 and 7). ${ }^{25}$ Having academic inventors among the authors does not have a significant effect on the number of citations received and even a negative and significant effect on the journal rank of articles with IRI authors.

\section{\{Table 3 around here\}}

We now limit the analysis to articles with academic inventors in order to examine what characteristics of academic inventors captured by the dummy variable in the previous regressions are more strongly associated with scientific impact: visibility, number of patents owned by academic institutions, number of patents not owned by academic institutions and number of years since first patent. In doing so, we consider two subsamples of articles with academic inventors: those without IRI authors $(13,906)$ and those with IRI authors $(1,693)$ (Table 4).

Let us first consider the negative binomial estimations of citations received by articles with academic inventors for the subsamples of articles without IRI authors (regression 1) and with IRI authors (regression 2). Interestingly, the marginal effect of the visibility of Spanish academic inventors on citations is positive and of a similar magnitude to the marginal effect of the visibility of their Spanish co-authors when considering articles without IRI authors, but it is not significant for articles with IRI authors. The number of patents owned by academic institutions has a positive effect of similar magnitude with or without IRI authors, but the coefficient is not significant for articles with IRI authors. ${ }^{26}$ The number of patents not owned by academic institutions is non-significant

\footnotetext{
${ }^{25}$ Results for universities, CSIC and MOC authors are available as Supplementary Material.

${ }^{26}$ Coefficients are not different according to Chow tests.
} 
for citations to articles without IRI authors, but it is negative and significant for citations to articles with IRI authors. ${ }^{27}$ Finally, the number of years since the first patent has a negative and significant effect on citations to articles without IRI authors and a negative but not significant effect for citations to articles with IRI authors. Patents not owned by academic institutions are more likely to be the result of contract research and consulting, which would be less closely related to high impact research (Jensen et al., 2011), and authors with old patents may no longer be publishing high impact articles, given lifecycle aging effects (Levin and Stephan, 1991). On the other hand, IRIs are relatively young centres, the age structure is younger, foreign researchers are more highly represented and turnover is higher than in other PROs.

Ordinary least squares estimations of the journal rank of articles with academic inventors offer similar results. Neither the visibility of Spanish academic inventors nor the visibility of their Spanish co-authors has a significant effect on the journal rank of articles with IRI authors. The number of patents not owned by academic institutions has a negative and significant effect on the journal rank of articles with IRI authors, whereas the number of patents owned by academic institutions has a positive and weakly significant effect.

\section{\{Table 4 around here $\}$}

According to both measures of scientific impact, citations and journal rank, the number of patents owned by academic institutions has a positive effect on citations received by articles of academic inventors with IRI authors, although it is not significant for citations received and only weakly significant for journal rank. In contrast, the number of patents not owned by academic institutions has a significant negative effect on both measures consistently, conditional on the length of the patenting experience of

\footnotetext{
${ }^{27}$ Coefficients are different only with a 5\% level of significance according to Chow tests.
} 
the academic inventors.

\section{Discussion and conclusions}

Our findings indicate that there is a positive statistical association, on aggregate, between past patenting experience of authors and scientific impact of academic articles, measured both in terms of raw number of citations received and journal prestige. Results for institutional subsamples offer a more nuanced view. The positive association between academic inventors and scientific impact holds for articles with authors from public universities and traditional PROs, but not for the highly cited articles published in highly ranked journals with authors from IRIs, which are relatively new centres aiming to optimise the conditions favourable for carrying out research on Pasteur's Quadrant, mainly, but not only active in life sciences fields.

We can advance three possible explanations for this result. First, research staff at IRIs may have a dual structure, probably dictated by subfield specialisations, with some researchers focusing on more basic research and other researchers doing more applied research. The latter would be those more likely to have past patenting activity and would also be, at the margin, those with lower impact publications. This conjecture is consistent with Calderini et al. (2007) who stress the importance of individual research trajectories and differences between applied and more fundamental research, when studying the propensity to patent of academic researchers. Second, the relationship between past patenting experience and scientific impact of articles seems to have a nonlinear shape. Having patenting experience may be positively correlated with scientific impact for lower values of scientific impact, but may not be significantly correlated for higher values of scientific impact. In other words, the citation advantage provided by academic inventors diminishes in environments where the scientific impact of articles is 
already quite high on average. Calderini et al. (2007) also observe a curvilinear effect of publication-related indicators on the hazard to patent, noting that "patents are more likely to come from medium-to-high impact research. Yet, scientists engaged in very high impact research seem to be less likely to patent, especially if they are also very productive.” A third factor needs to be taken into account: it may be too soon to assess the association of patenting experience of authors and scientific impact of IRI articles. These centres are relatively new and tend to hire either young and promising or established and renowned researchers. They are also characterised by a high turnover of research staff and recruitment is from international job markets, which means that previous patenting and publishing records of many IRI researchers might be associated with foreign institutions and thus not observed in our data.

As regards policy implications, our findings suggest that the innovative institutional arrangements (in the Spanish research organisational field) that characterise the IRIs, as newly created research centres in Pasteur's Quadrant areas, have successfully managed to achieve the highest scientific impact. The role played by patents in that process, as indicators of the extent to which they have also succeeded in carrying out use-inspired research, is not so clear. It might be too early to know. Not only are the IRIs relatively new and the age structure of their research staff younger than in other PROs, but also other metrics might be more appropriate than patents to measure the ability of researchers to do research that is at the same time fundamental and applied in nature, such as capacity to attract business funding, or involvement in cooperative research projects with industry and in translational medicine.

To conclude, our results should not be interpreted as implying causality and are not without limitations. As mentioned earlier, we lack data on the personal characteristics of researchers and our sample only includes SCOPUS articles written by active authors 
with patenting experience at the EPO. Nevertheless, our findings are suggestive of the relative importance of some observable characteristics of the scientific articles and the academic inventors amongst their authors, and of how that may change across different types of academic institutions. Our approach, by taking the article as the unit of observation seems to be in line with the metrics which are increasingly used to evaluate the performance of researchers and institutions, where having articles amongst the top cited or in top journals is a priority. Further research should look deeper into differences across academic institutions and their interplay with other determinants of scientific impact and patenting.

\section{Acknowledgements}

We would like to thank Francesco Lissoni, Natalia Zinovyeva, Luis Sanz-Menendez, Koen Jonkers, Félix de Moya, Katrin Hussinger, Bart van Looy and three anonymous referees for very useful comments and suggestions. We are also very grateful to Félix de Moya and Elena Corera from the SCImago Group for their help with the SCOPUS data. This work has also benefited greatly from comments of participants at the ESF-APEINV 'Scientists and Inventors’ workshop, Katholieke Universiteit Leuven (10-11 May 2012) and the EPIP Conference 'IP in motion', Leuven (27-28 September 2012). We acknowledge funding from the Spanish National Plan (CSO2009-10845).

\section{References}

Agrawal, A. and Henderson, R. (2002) Putting patents in context: exploring knowledge transfer from MIT, Management Science, 48(1), 44-60. 
Arnold, E., Barker, K. and S. Slipersaeter (2010) Research institutes in the ERA, WP2 2007/S106-12999 Foresight 200702 Lot2 WP3. Technopolis Group, NIFU Step, Manchester Business School.

Azagra-Caro, J.M. (2011) Do public research organisations own most patents invented by their staff? Science and Public Policy, 38(3), 237-250.

Azagra-Caro, J.M., Archontakis, F. and Yegros-Yegros, A. (2007) In which regions do universities patent and publish more? Scientometrics, 70(2), 251-266.

Azagra-Caro, J.M., Plaza-Gómez, L. and Romero-de-Pablos, A. (2007) The origin of public research organisation patents: an economic approach, Research Evaluation, 16(4), 271-282.

Azoulay, P., Ding., W. and Stuart, T. (2009) The impact of academic patenting on the rate, quality and direction of (public) research output, Journal of Industrial Economics, 57(4), 637-676.

Bach, L. and Llerena, P. (2007) Indicators of higher-education institutes and public-research organizations technology transfer activities: insights from France, Science and Public Policy, 34(10), 709-721.

Baldini, N. (2009) Implementing Bayh-Dole-like laws: Faculty problems and their impact on university patenting activity, Research Policy, 38, 1217-1224.

Blanco, A. (1999) Protección juridical de las invenciones universitarias y laborales, Editorial Aranzadi, Pamplona.

Bozeman, B. and Boardman, P.C. (2003) Managing the New Multipurpose, Multidiscipline University Research Centers: Institutional Innovation in the Academic Community, IBM Center for the Business of Government, Arlington, VA. http://archive.cspo.org/rvm/reports/reports_docs/IBM_Centers.pdf

Breschi, S., Lissoni, F. and Montobbio, F. (2008) University patenting and scientific productivity: a quantitative study of Italian academic inventors, European Management Review, 5, 91-109.

Buenstorf, G. (2009), Is commercialization good or bad for science? Individual-level evidence from the Max Planck Society. Research Policy, 38, 281-292.

Calderini, M., Franzoni, C. and Vezzulli, A. (2007) If star scientists do not patent: the effect of productivity, basicness and impact on the decision to patent in the academic world, Research Policy, 36, 303-319.

Cesaroni, F. and Piccaluga, A. (2005) Universities and Intellectual Property Rights in Southern European Countries. Technology Analysis \& Strategic Management, 17(4), 497-518. 
Cruz-Castro, L. and Sanz-Menendez L. (2007a) New legitimation models and the transformation of the public research organizational field, International Studies of Management and Organization, 37(1), 27-52.

Cruz-Castro, L. and Sanz-Menendez, L. (2007b) 'Research Evaluation in Transition', Sociology of the Sciences Yearbook, Vol. 26, pp. 205-223.

Cruz-Castro, L., Sanz-Menendez, L. and Martinez, C. (2012) Research centers in transition: patterns of convergence and diversity, Journal of Technology Transfer, 37, 18-42.

Czarnitzki, D., Glänzel, W., Hussinger, K. (2009). Heterogeneity of patenting activity and its implications for scientific research, Research Policy, 38, 26-34.

Fabrizio, K.R. and Di Minin, A. (2008). Commercializing the laboratory: Faculty patenting and the open science environment, Research Policy, 37, 914-931.

Fok, D. and Franses, P.H. (2007) Modelling the diffusion of scientific publications, Journal of Econometrics, 139, 376-390.

Forti, E., Franzoni, C. and Sobrero, M. (2013) Bridges or isolates? Investigatingthe social networks of academic inventors, Research Policy (forthcoming)

Frenken, K., Hölzl, W. and de Vor, F. (2005) The citation impact of research collaborations: the case of European biotechnology and applied microbiology (1988-2002), Journal of Engineering and Technology Management, 22, 9-30.

Gans, J., Murray, F. and Stern, S. (2011) Contracting over the disclosure of scientific knowledge: intellectual property and academic publication. Available at SSRN: http://ssrn.com/abstract=1559871 or http://dx.doi.org/10.2139/ssrn.1559871.

Garcia, C.E. and Sanz-Menendez, L (2003), 'The Evolution of Knowledge Management Strategies in PROs', in OECD (2003) Turning Science into Business, Paris: pp. 203-222 DOI: http://dx.doi.org/10.1787/9789264100244-13-en;

Goldfarb, B., Marschke, G. and Smith, A. (2009) Scholarship and innovative activity in the university: complements or substitutes? Economics of Innovation and New Technology, 18(8), 743-756.

González-Pereira, B., Guerrero-Bote, V.P. and Moya-Ayegón, F. (2010), A new approach to the metric of journal's scientific prestige: the SJR indicator, Journal of Informetrics, 4, 379-391. 
Haslam, N., Ban, L., Kaufmann, L., Loughnan, S., Peters, P., Whelan, J. and Wilson, S. (2008) What makes an article influential? Predicting impact in social and personality psychology, Scientometrics, 76(1), 169-185.

Jensen, R., Thursby, J, and Thursby, M. (2011) University-industry spillovers, government funding and industrial consulting, NBER Working Paper 15732, National Bureau of Economic Research.

Levin, S.G. and Stephan, P. (1991), Research productivity over the life cycle: evidence for academic scientists, American Economic Review, 81, 114-132.

Lissoni, F., Llerena, P. and B. Sanditov (2013) Inventors’ small worlds: academic and CNRS researchers in networks of inventors in France, Industry and Innovation 20(3), 195-220.

Maraut, S. and Martinez, C. (2013), Identifying author-inventors from Spain: methods and a first insight into results. Working Paper Instituto de Políticas y Bienes Públicos, 2013/2, IPP-CCHS, CSIC, Madrid.

Mejer, M. (2011). Entrepreneurial Scientists and their Publication Performance. An Insight from Belgium. ECARES Working Paper 2011-017.

Meyer, M. (2006) Are patenting scientists the better scholars? An exploratory comparison of inventorauthors with their non-inventing peers in nano-science and technology, Research Policy, 35, 16461662.

Mingers, J. and Xu, F. (2010) The drivers of citations in management science journals, European Journal of Operational Research, 205, 422-430.

Mora, J.G. (2001) The academic profession in Spain: between the civil service and the market, Higher Education, 41, 131-155.

Moutinho, P.S.F., Fontes, M. and Godinho, M.M. (2007) Do individual factors matter? A survey of scientists’ patenting in Portuguese public research organizations, Scientometrics, 70(2), 355-377.

Murray, F. and Stern, S. (2007) Do formal intellectual property rights hinder the free flow of scientific knowledge? An empirical test of the anti-commons hypothesis, Journal of Economic Behavior \& Organization, 63, 648-687.

OECD (2011a), Science, Technology and Industry Scoreboard 2011, OECD, Paris.

OECD (2011b), Actor brief on public research organisations; OECD, Paris. Available at http://www.oecd.org/innovation/policyplatform/48136051.pdf 
Osuna, C., Cruz-Castro, L. and Sanz-Menendez, L. (2011) Overturning some assumptions about the effects of evaluation systems of publications, Scientometrics, 86(3), 575-592

Potì, B. and Reale, E. (2005) The patenting regime in the Italian public research system. What motivates public inventors to patent. CERIS-CNR Working Paper, 10/2005.

Sanz-Menendez, L. (1995). Research actors and the state: Research evaluation and evaluation of science and technology policies in Spain. Research Evaluation, 5(1), 79-88

Sanz-Menendez, L. and Cruz-Castro, L. (2003) Coping with environmental pressures: public research organisations responses to funding crises. Research Policy 32 (8): 1293-1308

Sanz-Menendez, L. and L. Cruz-Castro (2011) La investigación y sus actores: institutos y centros de I+D y sus desafíos. Informe CYD 2009, Barcelona: Fundación CYD.

SCImago (2011) SCImago Institutions Ranking. SIR World Report 2011: Global Ranking, Retrieved January 08, 2012 from http://www.scimagoir.com/pdf/sir_2011_world_report.pdf.

Stephan, P., Gurmu, S., Sumell, A. and Black, G. (2007) Who’s patenting in the university? Evidence from the survey of doctorate recipients. Economics of Innovation and New Technology, 16, 2, 71-99

Stokes, D. (1997) Pasteur's Quadrant - Basic Science and Technological Innovation, Brookings Institution Press.

Stremersch, S., Verniers, I. and Verhoef, P.C. (2007) The quest for citations: drivers of article impact, Journal of Marketing, 71(3), 171-193.

Van Looy, B., Callaert, J., Debackere, K. (2006a). Publication and patent behaviour of academic researchers: Conflicting, reinforcing or merely co-existing? Research Policy, 35, 596-608.

Van Looy, B., du Plessis, M. and Magerman, T. (2006b) Data production methods for harmonized patent indicators; assignee sector allocation. Eurostat. Working Paper and Studies. Luxembourg.

Wong, P.K. and Singh, A. (2010) University patenting activities and their link to the quantity and quality of scientific publications, Scientometrics, 83, 271-294. 
Tables and Figures 
Table 1. Descriptive statistics

\begin{tabular}{|c|c|c|c|c|c|c|c|c|c|c|c|c|c|c|c|}
\hline \multicolumn{4}{|c|}{$\begin{array}{l}\text { All academic articles, 2003-2008 } \\
\qquad(\mathrm{n}=132,337)\end{array}$} & \multicolumn{4}{|c|}{$\begin{array}{l}\text { Academic articles with academic } \\
\text { inventors, 2003-2008 } \\
(\mathrm{n}=17,452)\end{array}$} & \multicolumn{4}{|c|}{$\begin{array}{l}\text { Academic articles with IRI authors, } \\
2004-2008 \\
(n=7,341)\end{array}$} & \multicolumn{4}{|c|}{$\begin{array}{l}\text { Academic articles with IRI authors and } \\
\text { academic inventors, 2004-2008 } \\
\qquad(\mathrm{n}=1,693)\end{array}$} \\
\hline Mean & SD & Min & Max & Mean & SD & Min & Max & Mean & SD & Min & Max & Mean & SD & Min & Max \\
\hline 2005.79 & 1.69 & 2003 & 2008 & 2005.92 & 1.65 & 2003 & 2008 & 2006.45 & 1.35 & 2004 & 2008 & 2006.56 & 1.32 & 2004 & 2008 \\
\hline 7.92 & 17.08 & 0 & 1990 & 9.96 & 17.58 & 0 & 879 & 12.15 & 26.06 & 0 & 1063 & 11.44 & 24.09 & 0 & 644 \\
\hline 0.30 & 0.62 & 0 & 19.5 & 0.45 & 0.77 & 0 & 14.1 & 0.71 & 1.18 & 0 & 16.91 & 0.83 & 1.14 & 0 & 12.5 \\
\hline 6.03 & 24.92 & 1 & 3031 & 5.96 & 23.20 & 1 & 2907 & 13.24 & 55.22 & 1 & 893 & 7.87 & 22.15 & 1 & 893 \\
\hline 0.40 & 0.49 & 0 & 1 & 0.35 & 0.48 & 0 & 1 & 0.48 & 0.50 & 0 & 1 & 0.40 & 0.49 & 0 & 1 \\
\hline 0.13 & 0.34 & 0 & 1 & 1.00 & 0.00 & 1 & 1 & 0.23 & 0.42 & 0 & 1 & 1.00 & 0.00 & 1 & 1 \\
\hline 5.65 & 7.18 & 0 & 214.4 & 6.21 & 7.84 & 0 & 198.8 & 9.92 & 11.32 & 0 & 153.5 & 8.50 & 9.21 & 0 & 80.6 \\
\hline & & & & 9.41 & 9.92 & 0 & 191 & & & & & 12.16 & 11.86 & 0 & 83.8 \\
\hline & & & & 2.03 & 7.95 & 0 & 80 & & & & & 0.88 & 1.99 & 0 & 66 \\
\hline & & & & 1.79 & 3.71 & 0 & 112 & & & & & 3.34 & 4.99 & 0 & 41 \\
\hline & & & & 6.62 & 5.18 & 0 & 25 & & & & & 6.30 & 4.59 & 0 & 23 \\
\hline 0.80 & 0.40 & 0 & 1 & 0.68 & 0.47 & 0 & 1 & 0.57 & 0.49 & 0 & 1 & 0.61 & 0.49 & 0 & 1 \\
\hline 0.23 & 0.42 & 0 & 1 & 0.39 & 0.49 & 0 & 1 & 0.18 & 0.38 & 0 & 1 & 0.20 & 0.40 & 0 & 1 \\
\hline 0.05 & 0.22 & 0 & 1 & 0.05 & 0.22 & 0 & 1 & 0.03 & 0.17 & 0 & 1 & 0.03 & 0.16 & 0 & 1 \\
\hline 0.06 & 0.24 & 0 & 1 & 0.10 & 0.30 & 0 & 1 & 1.00 & 0.00 & 1 & 1 & 1.00 & 0.00 & 1 & 1 \\
\hline
\end{tabular}

Publication year

Journal rank

Number of authors

Foreign author dummy

Academic inventor dummy

Visibility not academic inventors*

Visibility academic inventors*

Patents academic-owned

Patents not academic-owned

Years since first patent

University authors

CSIC authors

MOC authors

$0.06 \quad 0.24$

*Visibility variables for Spanish authors, academic inventors and others are only available for 2004-2008. Descriptive statistics for scientific fields available as Supplementary Material. 
Table 2. Average scientific impact of articles with different types of academic authors

\begin{tabular}{|c|c|c|c|c|c|c|c|c|}
\hline & \multicolumn{4}{|c|}{ Mean citations received } & \multicolumn{4}{|c|}{ Mean journal rank } \\
\hline & $\begin{array}{c}\text { Without } \\
\text { academic } \\
\text { inventors }\end{array}$ & $\begin{array}{c}\text { With } \\
\text { academic } \\
\text { inventors }\end{array}$ & Diff & Sig & $\begin{array}{c}\text { Without } \\
\text { academic } \\
\text { inventors }\end{array}$ & $\begin{array}{c}\text { With } \\
\text { academic } \\
\text { inventors }\end{array}$ & Diff & Sig \\
\hline All articles & 7.62 & 9.96 & -2.34 & $* * *$ & 0.27 & 0.45 & -0.18 & $* * *$ \\
\hline Articles with university authors & 7.17 & 9.22 & -2.04 & $* * *$ & 0.24 & 0.39 & -0.15 & $* * *$ \\
\hline Articles without university authors & 9.54 & 11.55 & -2.01 & $* * *$ & 0.43 & 0.58 & -0.15 & $* * *$ \\
\hline Articles with CSIC authors & 9.03 & 10.84 & -1.81 & $* * *$ & 0.38 & 0.56 & -0.17 & $* * *$ \\
\hline Articles without CSIC authors & 7.26 & 9.39 & -2.13 & $* * *$ & 0.25 & 0.38 & -0.13 & $* * *$ \\
\hline Articles with MOC authors & 7.18 & 9.09 & -1.91 & $* * *$ & 0.24 & 0.46 & -0.22 & $* * *$ \\
\hline Articles without MOC authors & 7.64 & 10.01 & -2.37 & $* * *$ & 0.28 & 0.45 & -0.18 & $* * *$ \\
\hline Articles with IRI authors & 13.49 & 12.37 & 1.12 & & 0.67 & 0.86 & -0.19 & $* * *$ \\
\hline Articles without IRI authors & 7.28 & 9.68 & -2.40 & $* * *$ & 0.25 & 0.41 & -0.15 & $* * *$ \\
\hline
\end{tabular}


Figure1. Distribution of articles and difference with respect to annual mean of citations received

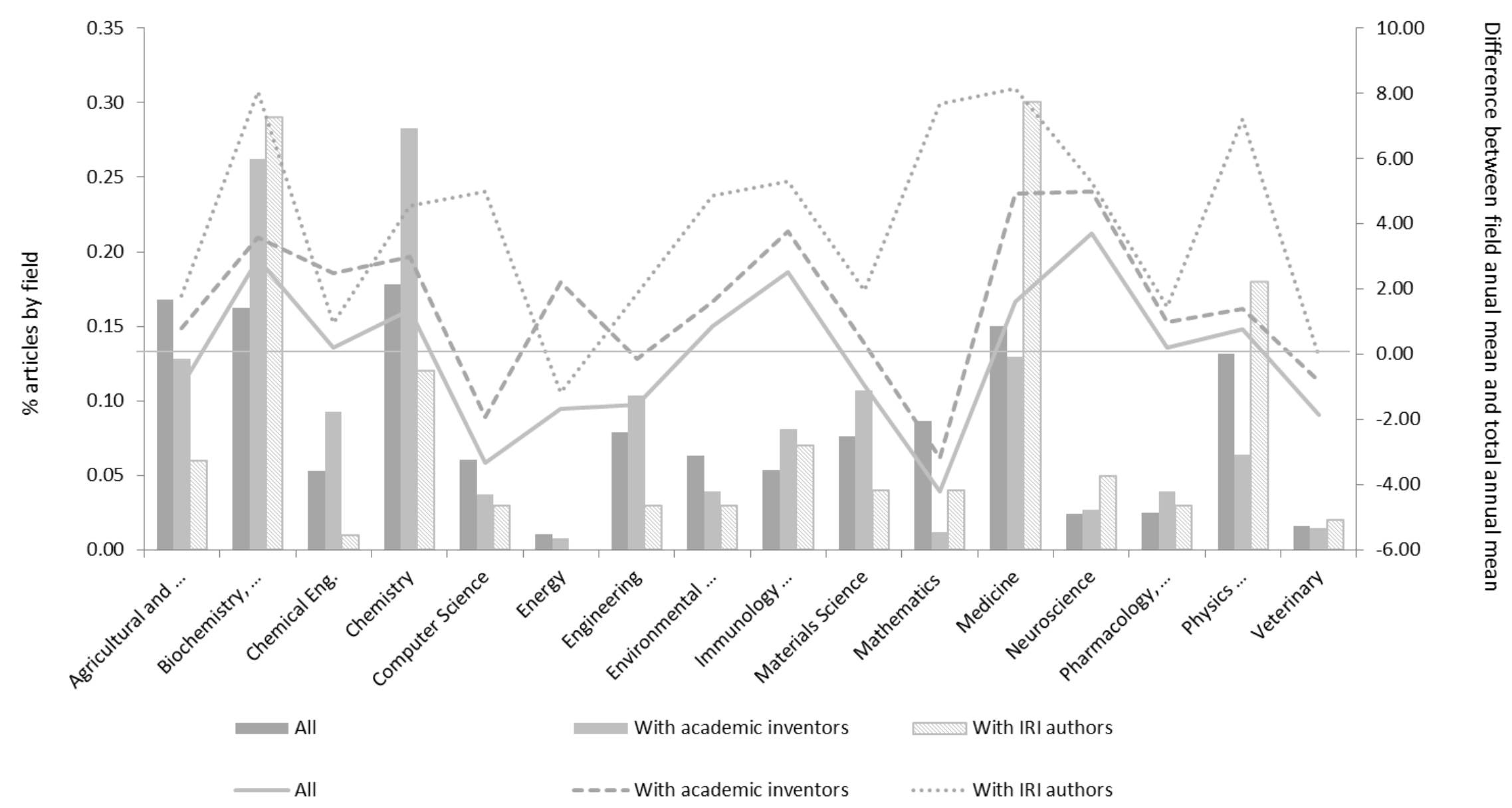


Table 3. Scientific impact of academic articles

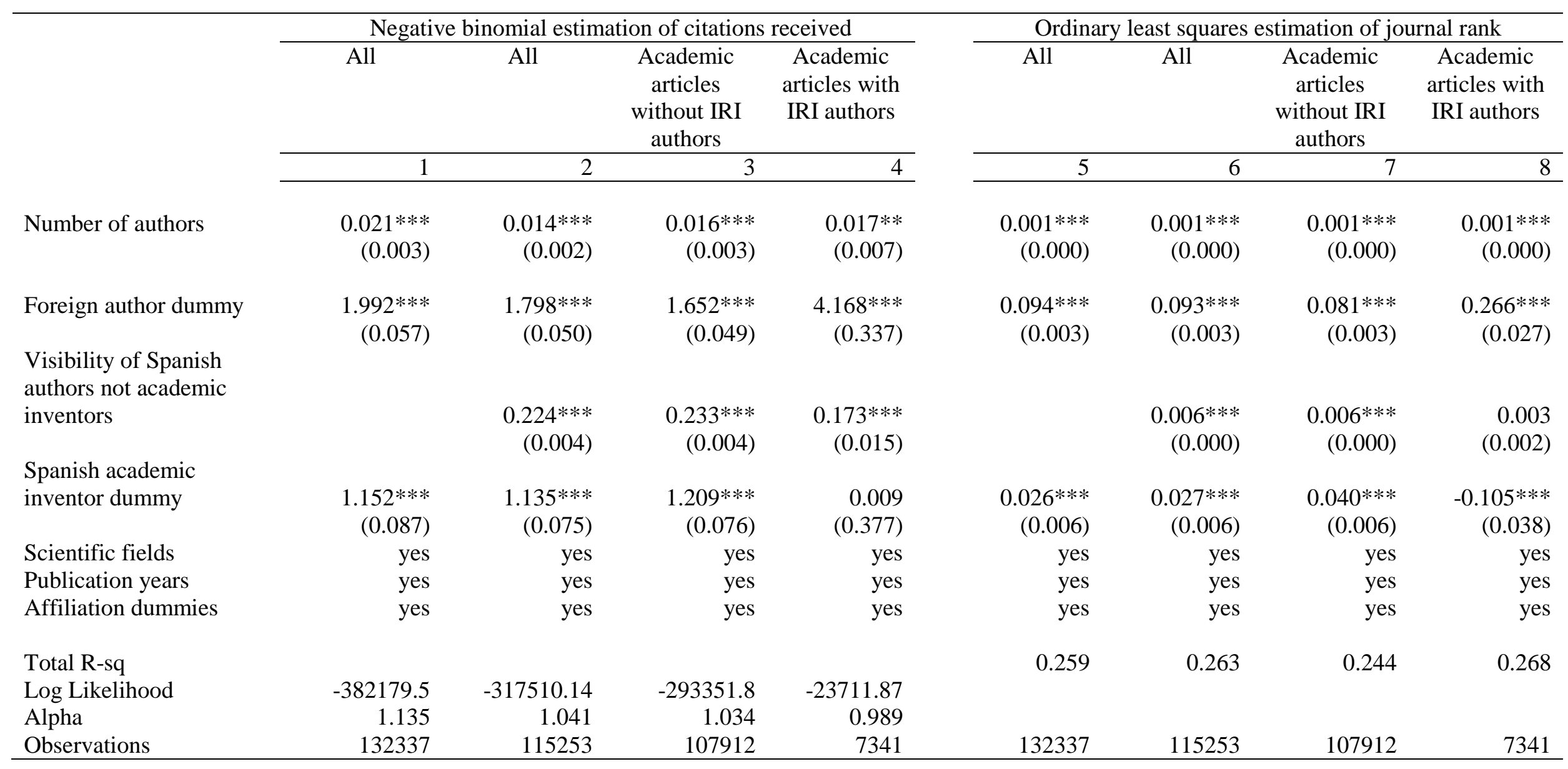

${ }^{*} \mathrm{p}<0.1 ; * * \mathrm{p}<0.05 ; * * * \mathrm{p}<0.01$. Marginal effects for negative binomial estimations. Robust standard errors in parentheses. 
Table 4. Scientific impact of articles with academic inventors

\begin{tabular}{|c|c|c|c|c|}
\hline & \multicolumn{2}{|c|}{$\begin{array}{c}\text { Negative binomial } \\
\text { estimation of citations received }\end{array}$} & \multicolumn{2}{|c|}{$\begin{array}{c}\text { Ordinary least squares } \\
\text { estimation of journal rank }\end{array}$} \\
\hline & $\begin{array}{l}\text { Articles without } \\
\text { IRI authors }\end{array}$ & $\begin{array}{l}\text { Articles with IRI } \\
\text { authors }\end{array}$ & $\begin{array}{c}\text { Articles without IRI } \\
\text { authors }\end{array}$ & $\begin{array}{c}\text { Articles with IRI } \\
\text { authors }\end{array}$ \\
\hline & 1 & 2 & 3 & 4 \\
\hline \multirow[t]{2}{*}{ Number of authors } & 0.095 & 0.038 & 0.000 & $0.003^{*}$ \\
\hline & $(0.169)$ & $(0.055)$ & $(0.000)$ & $(0.002)$ \\
\hline \multirow[t]{2}{*}{ Foreign author dummy } & $0.983^{* *}$ & $2.782 * * *$ & $0.105^{* * *}$ & $0.290 * * *$ \\
\hline & $(0.448)$ & $(0.530)$ & $(0.012)$ & $(0.058)$ \\
\hline \multirow{2}{*}{ Visibility of Spanish authors not academic inventors } & $0.128 * * *$ & $0.116^{* * *}$ & 0.002 & 0.005 \\
\hline & $(0.016)$ & $(0.028)$ & $(0.001)$ & $(0.004)$ \\
\hline \multicolumn{5}{|l|}{ Characteristics of Spanish academic inventors: } \\
\hline \multirow[t]{2}{*}{ Visibility } & $0.119 * * *$ & 0.032 & $0.007 * * *$ & 0.003 \\
\hline & $(0.012)$ & $(0.025)$ & $(0.001)$ & $(0.003)$ \\
\hline \multirow[t]{2}{*}{ Number of patents owned by academic institutions } & $0.054 * * *$ & 0.035 & $0.003^{* * *}$ & $0.040^{*}$ \\
\hline & $(0.014)$ & $(0.102)$ & $(0.001)$ & $(0.021)$ \\
\hline \multirow[t]{2}{*}{ Number of patents not owned by academic institutions } & 0.003 & $-0.119 * *$ & -0.004 & $-0.029 * * *$ \\
\hline & $(0.026)$ & $(0.051)$ & $(0.003)$ & $(0.007)$ \\
\hline \multirow[t]{2}{*}{ Years since first patent } & $-0.029 * *$ & -0.038 & $0.003 * *$ & -0.002 \\
\hline & $(0.014)$ & $(0.075)$ & $(0.001)$ & $(0.010)$ \\
\hline Scientific fields & yes & yes & yes & yes \\
\hline Publication years & yes & yes & yes & yes \\
\hline Affiliation dummies & yes & yes & yes & yes \\
\hline Total R-sq & & & 0.293 & 0.269 \\
\hline Log Likelihood & -41188.6 & -5338.491 & & \\
\hline Alpha & 0.785 & 0.707 & & \\
\hline Observations & 13906 & 1693 & 13906 & 1693 \\
\hline
\end{tabular}

${ }^{*} \mathrm{p}<0.1 ; * * \mathrm{p}<0.05 ; * * * \mathrm{p}<0.01$. Marginal effects for negative binomial estimations. Robust standard errors in parentheses. 


\section{SUPPLEMENTARY MATERIAL}

Table S1. Distribution of academic articles by field for all academic articles and articles with IRI authors

Agricultural and Biological Sciences

Biochemistry, Genetics and Molecular Biology

Chemical Engineering

Chemistry

Computer Science

Energy

Engineering

Environmental Science

Immunology and Microbiology

Materials Science

Mathematics

Medicine

Neuroscience

Pharmacology, Toxicology and Pharmaceutics

Physics and Astronomy

Veterinary

\begin{tabular}{|c|c|}
\hline \multicolumn{2}{|c|}{$\begin{array}{c}\text { All academic articles, } \\
2003-2008 \\
(n=132,337)\end{array}$} \\
\hline Mean & SD \\
\hline 0.17 & 0.37 \\
\hline 0.16 & 0.37 \\
\hline 0.05 & 0.22 \\
\hline 0.18 & 0.38 \\
\hline 0.06 & 0.24 \\
\hline 0.01 & 0.10 \\
\hline 0.08 & 0.27 \\
\hline 0.06 & 0.24 \\
\hline 0.05 & 0.23 \\
\hline 0.08 & 0.27 \\
\hline 0.09 & 0.28 \\
\hline 0.15 & 0.36 \\
\hline 0.02 & 0.15 \\
\hline 0.02 & 0.16 \\
\hline 0.13 & 0.34 \\
\hline 0.02 & 0.12 \\
\hline
\end{tabular}

\begin{tabular}{|c|c|}
\hline $\begin{array}{r}\text { Academ } \\
\text { with a } \\
\text { inventors, } \\
(\mathrm{n}=1\end{array}$ & $\begin{array}{l}\text { icles } \\
\text { iic } \\
-2008 \\
\end{array}$ \\
\hline Mean & SD \\
\hline 0.13 & 0.33 \\
\hline 0.26 & 0.44 \\
\hline 0.09 & 0.29 \\
\hline 0.28 & 0.45 \\
\hline 0.04 & 0.19 \\
\hline 0.01 & 0.09 \\
\hline 0.10 & 0.30 \\
\hline 0.04 & 0.19 \\
\hline 0.08 & 0.27 \\
\hline 0.11 & 0.31 \\
\hline 0.01 & 0.11 \\
\hline 0.13 & 0.34 \\
\hline 0.03 & 0.16 \\
\hline 0.04 & 0.20 \\
\hline 0.06 & 0.24 \\
\hline 0 & 0.12 \\
\hline
\end{tabular}

Articles with IRI

authors, 2004-2008

$(n=7,341)$

Articles with IRI authors

and with academic

inventors, 2004-2008

$(n=1,693)$ 
Figure S1.Distribution of articles and difference with respect to annual mean of journal rank

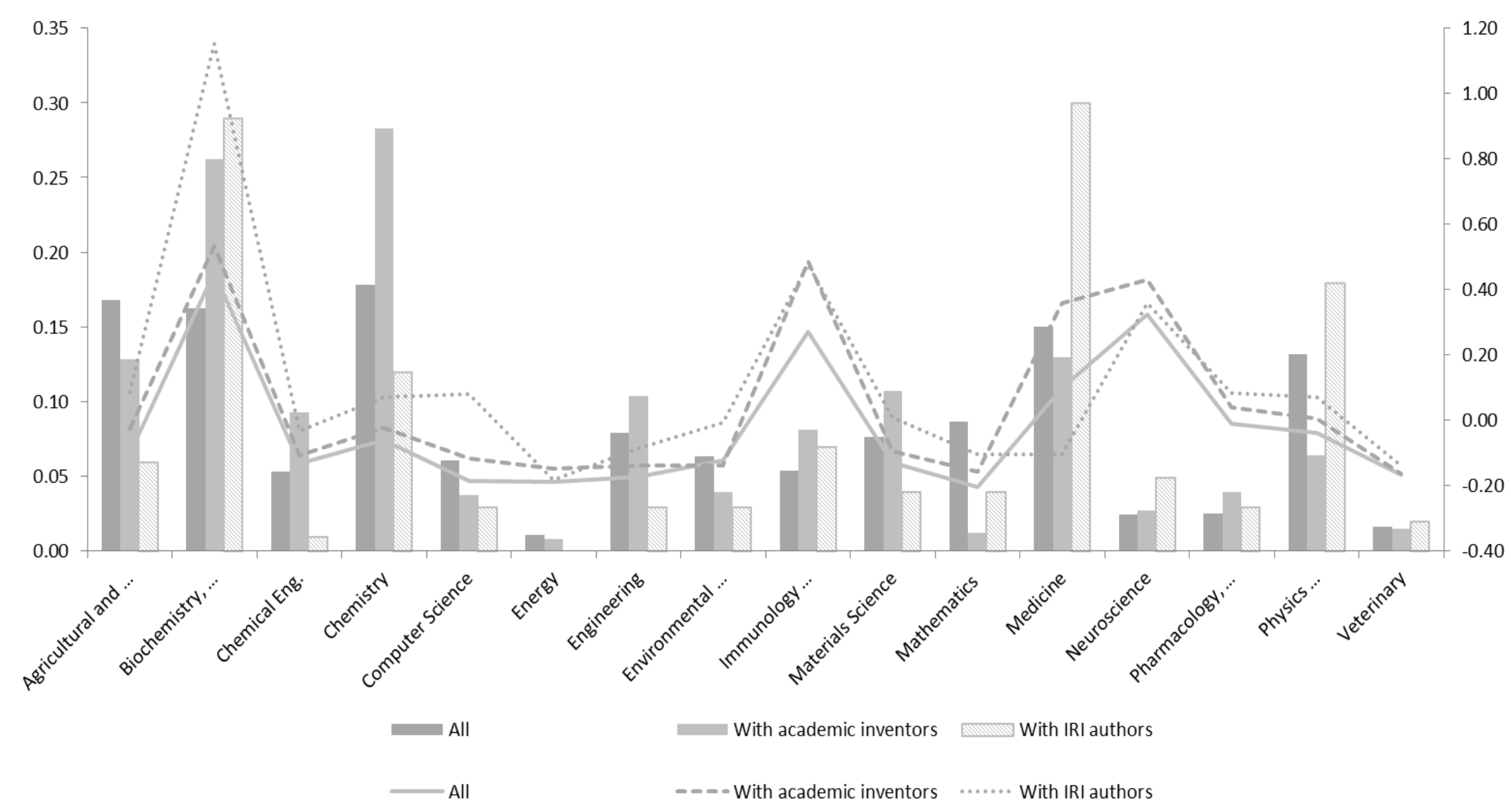


Table S2. Descriptive statistics for academic articles with university, CSIC and MOC authors, 2004-2008

\begin{tabular}{|c|c|c|c|c|c|c|c|c|c|c|c|c|}
\hline & \multicolumn{4}{|c|}{ University authors } & \multicolumn{4}{|c|}{ CSIC authors } & \multicolumn{4}{|c|}{ MOC authors } \\
\hline & \multirow{2}{*}{\multicolumn{2}{|c|}{$\begin{array}{c}\text { All } \\
\mathrm{n}=91667\end{array}$}} & \multirow{2}{*}{\multicolumn{2}{|c|}{$\begin{array}{c}\text { With acad. inv. } \\
\mathrm{n}=10666\end{array}$}} & \multirow{2}{*}{\multicolumn{2}{|c|}{$\begin{array}{c}\text { All } \\
\mathrm{n}=26326\end{array}$}} & \multirow{2}{*}{\multicolumn{2}{|c|}{$\begin{array}{c}\text { With acad.inv. } \\
\mathrm{n}=6093\end{array}$}} & \multirow{2}{*}{\multicolumn{2}{|c|}{$\begin{array}{c}\text { All } \\
\mathrm{n}=5739\end{array}$}} & \multirow{2}{*}{\multicolumn{2}{|c|}{$\begin{array}{c}\text { With acad.inv. } \\
\mathrm{n}=836\end{array}$}} \\
\hline & & & & & & & & & & & & \\
\hline & Mean & SD & Mean & SD & Mean & SD & Mean & SD & Mean & SD & Mean & SD \\
\hline Citations received & 6.54 & 12.33 & 8.29 & 13.8 & 8.36 & 15.7 & 9.58 & 13.76 & 6.46 & 10.1 & 8.11 & 13.1 \\
\hline Journal rank & 0.25 & 0.49 & 0.39 & 0.64 & 0.42 & 0.77 & 0.55 & 0.85 & 0.27 & 0.51 & 0.44 & 0.66 \\
\hline Number of authors & 6.27 & 27.44 & 5.94 & 9.19 & 9.15 & 50.5 & 6.40 & 37.28 & 11.5 & 63.5 & 6.84 & 4.24 \\
\hline Foreign authors & 0.38 & 0.49 & 0.32 & 0.47 & 0.44 & 0.50 & 0.36 & 0.48 & 0.39 & 0.49 & 0.33 & 0.47 \\
\hline Academic inventors & 0.12 & 0.32 & 1.00 & 0.00 & 0.23 & 0.42 & 1.00 & 0.00 & 0.15 & 0.35 & 1.00 & 0.00 \\
\hline Visibility not academic inventors & 5.39 & 6.86 & 6.02 & 7.73 & 6.76 & 7.35 & 6.76 & 7.69 & & & 5.69 & 5.96 \\
\hline Visibility academic inventors & & & 8.65 & 9.81 & & & 10.5 & 9.45 & & & 7.67 & 7.61 \\
\hline Patents academic-owned & & & 1.17 & 3.44 & & & 3.93 & 12.73 & & & 1.39 & 2.70 \\
\hline Patents not academic-owned & & & 1.59 & 2.90 & & & 2.27 & 5.01 & & & 0.73 & 1.65 \\
\hline Years since first patent & & & 6.46 & 5.08 & & & 7.62 & 5.61 & & & 6.90 & 4.87 \\
\hline University authors & 1.00 & 0.00 & 1.00 & 0.00 & 0.32 & 0.47 & 0.34 & 0.47 & 0.40 & 0.49 & 0.41 & 0.49 \\
\hline CSIC authors & 0.09 & 0.29 & 0.20 & 0.40 & 1.00 & 0.00 & 1.00 & 0.00 & 0.16 & 0.37 & 0.24 & 0.43 \\
\hline MOC authors & 0.03 & 0.16 & 0.03 & 0.18 & 0.04 & 0.19 & 0.03 & 0.18 & 1.00 & 0.00 & 1.00 & 0.00 \\
\hline IRI authors & 0.05 & 0.21 & 0.10 & 0.30 & 0.05 & 0.22 & 0.06 & 0.23 & 0.04 & 0.19 & 0.06 & 0.23 \\
\hline Agricultural and Biological... & 0.15 & 0.36 & 0.12 & 0.33 & 0.23 & 0.42 & 0.13 & 0.34 & 0.46 & 0.50 & 0.33 & 0.47 \\
\hline Biochemistry, Genetics and... & 0.15 & 0.36 & 0.25 & 0.43 & 0.19 & 0.39 & 0.28 & 0.45 & 0.16 & 0.37 & 0.27 & 0.44 \\
\hline Chemical Engineering & 0.05 & 0.23 & 0.09 & 0.28 & 0.06 & 0.23 & 0.11 & 0.31 & 0.03 & 0.16 & 0.05 & 0.22 \\
\hline Chemistry & 0.18 & 0.38 & 0.28 & 0.45 & 0.20 & 0.40 & 0.32 & 0.46 & 0.06 & 0.24 & 0.10 & 0.30 \\
\hline Computer Science & 0.07 & 0.25 & 0.05 & 0.21 & 0.02 & 0.13 & 0.02 & 0.13 & 0.01 & 0.09 & 0.00 & 0.06 \\
\hline Energy & 0.01 & 0.10 & 0.01 & 0.09 & 0.01 & 0.08 & 0.01 & 0.08 & 0.04 & 0.19 & 0.03 & 0.16 \\
\hline Engineering & 0.09 & 0.29 & 0.13 & 0.34 & 0.04 & 0.21 & 0.06 & 0.25 & 0.02 & 0.15 & 0.03 & 0.17 \\
\hline Environmental Science & 0.06 & 0.24 & 0.04 & 0.20 & 0.09 & 0.28 & 0.04 & 0.19 & 0.08 & 0.28 & 0.05 & 0.22 \\
\hline Immunology and Microbiology & 0.05 & 0.21 & 0.06 & 0.25 & 0.07 & 0.25 & 0.10 & 0.30 & 0.13 & 0.34 & 0.22 & 0.41 \\
\hline Materials Science & 0.07 & 0.26 & 0.10 & 0.30 & 0.12 & 0.32 & 0.13 & 0.33 & 0.03 & 0.17 & 0.04 & 0.19 \\
\hline Mathematics & 0.10 & 0.30 & 0.01 & 0.12 & 0.03 & 0.17 & 0.01 & 0.07 & 0.01 & 0.09 & 0.00 & 0.07 \\
\hline Medicine & 0.16 & 0.36 & 0.14 & 0.35 & 0.07 & 0.25 & 0.08 & 0.28 & 0.18 & 0.38 & 0.20 & 0.40 \\
\hline Neuroscience & 0.02 & 0.15 & 0.03 & 0.16 & 0.02 & 0.15 & 0.02 & 0.16 & 0.01 & 0.10 & 0.02 & 0.13 \\
\hline Pharmacology, Toxicology... & 0.03 & 0.16 & 0.05 & 0.21 & 0.02 & 0.14 & 0.03 & 0.18 & 0.02 & 0.12 & 0.02 & 0.15 \\
\hline Physics and Astronomy & 0.13 & 0.33 & 0.07 & 0.25 & 0.17 & 0.38 & 0.07 & 0.25 & 0.07 & 0.26 & 0.03 & 0.17 \\
\hline Veterinary & 0.02 & 0.13 & 0.02 & 0.14 & 0.01 & 0.09 & 0.01 & 0.07 & 0.05 & 0.22 & 0.08 & 0.26 \\
\hline
\end{tabular}


Table S3. Negative binomial estimation of citations received by a published academic article: different authors' academic affiliations

\begin{tabular}{|c|c|c|c|c|c|c|}
\hline & $\begin{array}{c}\text { Without } \\
\text { universities }\end{array}$ & $\begin{array}{c}\text { With } \\
\text { universities }\end{array}$ & $\begin{array}{c}\text { Without } \\
\text { CSIC }\end{array}$ & $\begin{array}{l}\text { With } \\
\text { CSIC }\end{array}$ & $\begin{array}{c}\text { Without } \\
\text { MOC }\end{array}$ & $\begin{array}{l}\text { With } \\
\text { MOC }\end{array}$ \\
\hline & 1 & 2 & 3 & 4 & 5 & 6 \\
\hline Number of authors & $\begin{array}{r}0.063^{* *} \\
(0.028)\end{array}$ & $\begin{array}{r}0.010^{* * * *} \\
(0.002)\end{array}$ & $\begin{array}{r}0.071 * * * \\
(0.011)\end{array}$ & $\begin{array}{r}0.006 * * * \\
(0.002)\end{array}$ & $\begin{array}{r}0.018 * * * \\
(0.002)\end{array}$ & $\begin{array}{r}0.007 * * * \\
(0.003)\end{array}$ \\
\hline Foreign author dummy & $\begin{array}{r}1.641 * * * \\
(0.140)\end{array}$ & $\begin{array}{r}1.742 * * * \\
(0.054)\end{array}$ & $\begin{array}{r}1.676^{* * *} \\
(0.058)\end{array}$ & $\begin{array}{r}1.431^{* * *} \\
(0.104)\end{array}$ & $\begin{array}{r}1.799 * * * \\
(0.052)\end{array}$ & $\begin{array}{r}1.505 * * * \\
(0.165)\end{array}$ \\
\hline Visibility Spanish not academic inventors & $\begin{array}{r}0.178 * * * \\
(0.009)\end{array}$ & $\begin{array}{r}0.234^{* * * *} \\
(0.005)\end{array}$ & $\begin{array}{r}0.227 * * * \\
(0.005)\end{array}$ & $\begin{array}{r}0.180 * * * \\
(0.008)\end{array}$ & $\begin{array}{r}0.225^{* * *} * \\
(0.004)\end{array}$ & $\begin{array}{r}0.167 * * * \\
(0.014)\end{array}$ \\
\hline Spanish academic inventor dummy & $\begin{array}{r}0.781 * * * \\
(0.149)\end{array}$ & $\begin{array}{r}1.224^{* * *} \\
(0.087)\end{array}$ & $\begin{array}{r}1.261 * * * \\
(0.091)\end{array}$ & $\begin{array}{r}0.647 * * * \\
(0.124)\end{array}$ & $\begin{array}{r}1.128 * * * \\
(0.078)\end{array}$ & $\begin{array}{r}1.119 * * * \\
(0.262)\end{array}$ \\
\hline $\begin{array}{l}\text { Scientific fields } \\
\text { Publication years } \\
\text { Affiliation dummies }\end{array}$ & $\begin{array}{l}\text { yes } \\
\text { yes } \\
\text { yes }\end{array}$ & $\begin{array}{l}\text { yes } \\
\text { yes } \\
\text { yes }\end{array}$ & $\begin{array}{l}\text { yes } \\
\text { yes } \\
\text { yes }\end{array}$ & $\begin{array}{l}\text { yes } \\
\text { yes } \\
\text { yes }\end{array}$ & $\begin{array}{l}\text { yes } \\
\text { yes } \\
\text { yes }\end{array}$ & $\begin{array}{l}\text { yes } \\
\text { yes } \\
\text { yes }\end{array}$ \\
\hline $\begin{array}{l}\text { Log Likelihood } \\
\text { Alpha } \\
\text { Observations }\end{array}$ & $\begin{array}{r}-69959.28 \\
0.914 \\
23586\end{array}$ & $\begin{array}{r}-246870 \\
1.062 \\
91667\end{array}$ & $\begin{array}{r}-239390.3 \\
1.082 \\
88927\end{array}$ & $\begin{array}{r}-77170 \\
0.859 \\
26326\end{array}$ & $\begin{array}{r}-301896.4 \\
1.050 \\
109514\end{array}$ & $\begin{array}{r}-15342.93 \\
0.780 \\
5739\end{array}$ \\
\hline $\begin{array}{l}\text { Chow test: } \\
\text { Academic inventor dummy }\end{array}$ & $\begin{array}{r}\quad(1) \\
\text { chi2( } \\
\text { Prob }>\mathrm{c}\end{array}$ & 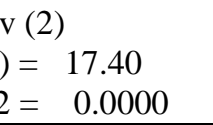 & $\begin{array}{r}\text { (3) } \\
\text { chi2( } \\
\text { Prob }>\mathrm{c}\end{array}$ & $\begin{array}{r}30.91 \\
0.0000\end{array}$ & $\begin{array}{l}(5) \\
\text { chi2( } \\
\text { Prob > }\end{array}$ & $\begin{array}{l}0.23 \\
=\quad 0.6309 \\
\end{array}$ \\
\hline
\end{tabular}

${ }^{*} \mathrm{p}<0.1 ; * * \mathrm{p}<0.05 ; * * * \mathrm{p}<0.01$. Marginal effects. Robust standard errors in parentheses. 
Table S4. Ordinary least squares estimation of the journal rank of a published academic article: different authors' academic affiliations

\begin{tabular}{|c|c|c|c|c|c|c|}
\hline & $\begin{array}{c}\text { Without } \\
\text { universities }\end{array}$ & $\begin{array}{c}\text { With } \\
\text { universities }\end{array}$ & $\begin{array}{l}\text { Without } \\
\text { CSIC }\end{array}$ & $\begin{array}{l}\text { With } \\
\text { CSIC }\end{array}$ & $\begin{array}{l}\text { Without } \\
\text { MOC }\end{array}$ & With MOC \\
\hline Number of authors & $\begin{array}{r}0.000 \\
(0.000)\end{array}$ & $\begin{array}{r}0.001^{* * *} \\
(0.000)\end{array}$ & $\begin{array}{r}0.002 * * * \\
(0.000)\end{array}$ & $\begin{array}{r}0.000 * * * \\
(0.000)\end{array}$ & $\begin{array}{r}0.001^{* * *} \\
(0.000)\end{array}$ & $\begin{array}{r}0.000 * * \\
(0.000)\end{array}$ \\
\hline Foreign author dummy & $\begin{array}{r}0.121^{* * *} \\
(0.010)\end{array}$ & $\begin{array}{r}0.080 * * * \\
(0.003)\end{array}$ & $\begin{array}{r}0.088 * * * \\
(0.004)\end{array}$ & $\begin{array}{r}0.091^{* * *} \\
(0.009)\end{array}$ & $\begin{array}{r}0.093 * * * \\
(0.004)\end{array}$ & $\begin{array}{r}0.081^{* * *} \\
(0.014)\end{array}$ \\
\hline $\begin{array}{l}\text { Visibility Spanish not } \\
\text { academic inventors }\end{array}$ & $\begin{array}{r}0.003 * * \\
(0.001)\end{array}$ & $\begin{array}{r}0.007 * * * \\
(0.000)\end{array}$ & $\begin{array}{r}0.007^{* * *} \\
(0.001)\end{array}$ & $\begin{array}{r}0.002 * * * \\
(0.001)\end{array}$ & $\begin{array}{r}0.006^{* * *} \\
(0.000)\end{array}$ & $\begin{array}{r}0.006^{* * *} \\
(0.001)\end{array}$ \\
\hline $\begin{array}{l}\text { Spanish academic inventor } \\
\text { dummy }\end{array}$ & $\begin{array}{r}-0.022 \\
(0.016)\end{array}$ & $\begin{array}{r}0.049 * * * \\
(0.006)\end{array}$ & $\begin{array}{r}0.044^{* * *} \\
(0.006)\end{array}$ & $\begin{array}{r}-0.018 \\
(0.014)\end{array}$ & $\begin{array}{r}0.026 * * * \\
(0.006)\end{array}$ & $\begin{array}{r}0.048 * * \\
(0.021)\end{array}$ \\
\hline Scientific fields & yes & yes & yes & yes & yes & yes \\
\hline Publication years & yes & yes & yes & yes & yes & yes \\
\hline Affiliation dummies & yes & yes & yes & yes & yes & yes \\
\hline $\begin{array}{l}\text { Total R-sq } \\
\text { Observations }\end{array}$ & $\begin{array}{r}0.303 \\
23586\end{array}$ & $\begin{array}{r}0.226 \\
91667\end{array}$ & $\begin{array}{r}0.223 \\
88927\end{array}$ & $\begin{array}{r}0.323 \\
26326\end{array}$ & $\begin{array}{r}0.265 \\
109514\end{array}$ & $\begin{array}{r}0.289 \\
5739\end{array}$ \\
\hline $\begin{array}{l}\text { Chow test: } \\
\text { Academic inventor dummy }\end{array}$ & $\begin{aligned} & c h \\
& \text { Prob }>\end{aligned}$ & $\begin{array}{l}2(1)=17.38 \\
\text { hi } 2=0.0000\end{array}$ & Prob & $\begin{array}{l}1)=16.64 \\
=\quad 0.0000\end{array}$ & Prob $>$ & $\begin{array}{l}2(1)=0.99 \\
\text { hi2 }=0.3205\end{array}$ \\
\hline
\end{tabular}

${ }^{*} \mathrm{p}<0.1 ; * * \mathrm{p}<0.05 ; * * * \mathrm{p}<0.01 .$. Robust standard errors in parentheses. 


\section{Annex S1: Examples of Spanish Independent Research Institutes and their missions}

\begin{tabular}{|c|c|c|c|c|}
\hline IRI & Acronym & Mission & Location & Created \\
\hline $\begin{array}{l}\text { Spanish National Research } \\
\text { Cancer Centre }\end{array}$ & CNIO & $\begin{array}{l}\text {...to carry out research of excellence and to offer innovative technologies } \\
\text { within the cancer field to the Spanish National Health System. }\end{array}$ & Madrid & 1998 \\
\hline $\begin{array}{l}\text { Donostia International } \\
\text { Physics Centre }\end{array}$ & DIPC & $\begin{array}{l}\text {...to promote and catalyse the development of basic research and basic } \\
\text { research oriented towards material science to reach the highest level. }\end{array}$ & $\begin{array}{l}\text { Basque } \\
\text { country }\end{array}$ & 1999 \\
\hline $\begin{array}{l}\text { Institute of Chemical } \\
\text { Research of Catalonia }\end{array}$ & $\mathrm{ICIQ}$ & $\begin{array}{l}\text {...research institute that provides the talent and leadership needed to improve } \\
\text { citizens' quality of life through the application of chemistry at the frontiers of } \\
\text { knowledge. }\end{array}$ & Catalonia & 2000 \\
\hline $\begin{array}{l}\text { National Centre for } \\
\text { Cardiovascular Research }\end{array}$ & CNIC & $\begin{array}{l}\text {...to bring together the best of Spanish cardiovascular research and provide it } \\
\text { with a modern infrastructure and ample funding to carry out world-leading } \\
\text { biomedical research...organised into three strategic departments which study } \\
\text { areas of fundamental interest identified as the most likely to lead to rapid } \\
\text { advances in medical practice. }\end{array}$ & Madrid & 2002 \\
\hline $\begin{array}{l}\text { Institute of Photonic } \\
\text { Sciences }\end{array}$ & ICFO & $\begin{array}{l}\text {...to advance the science of light and develop advanced light-based } \\
\text { technologies which would create new understanding, new solutions, and new } \\
\text { tools to help industry and society at large to tackle today's main challenges. }\end{array}$ & Catalonia & 2002 \\
\hline $\begin{array}{l}\text { Centro de Investigacion } \\
\text { Cooperativa Biogune }\end{array}$ & CIC-Biogune & $\begin{array}{l}\text {...research strategy resides in the firm belief that if talented researchers are } \\
\text { given the freedom and necessary means they will contribute to solve } \\
\text { fundamental biological questions...also firmly believe in the necessity to create } \\
\text { a lively intellectual environment with biotech companies that fosters creative } \\
\text { and innovative approaches to research and technological innovation. }\end{array}$ & $\begin{array}{l}\text { Basque } \\
\text { country }\end{array}$ & 2002 \\
\hline
\end{tabular}




\section{Annex S2. Matching and disambiguation methodology to identify Spanish author- inventors}

The matching and disambiguation methodology used to identify Spanish authorinventors is described at length in Maraut and Martinez (2013). It relies on countryspecific knowledge about customs for writing names (initials, abbreviations, order and number of surnames, dictionaries, etc.), and is characterised by the modular approach described in the table below.

Matching and disambiguation methodology

\begin{tabular}{|c|c|c|c|}
\hline $\begin{array}{c}\text { STEP 1: TEXT } \\
\text { STRUCTURATION }\end{array}$ & $\begin{array}{l}\text { STEP 2: NAME } \\
\text { MATCHING FOR } \\
\text { PERSONS AND } \\
\underline{\text { INSTITUTIONS }}\end{array}$ & $\begin{array}{l}\frac{\text { STEP 3: PERSON }}{\text { DISAMBIGUATION AND }} \\
\underline{\text { CLUSTERING }}\end{array}$ & $\begin{array}{l}\text { STEP 4: QUALITY CONTROL } \\
\text { AND RECURSIVE VALIDATION }\end{array}$ \\
\hline $\begin{array}{l}\text { I. DATA PREPARATION } \\
\text { - Cleaning } \\
\text { - } \quad \text { Tokenisation } \\
\text { - } \quad \text { Token control } \\
\text { III. TOKEN MATCHING } \\
\text { - Token blocking } \\
\text { - } \quad \text { Token matching } \\
\text { II. DATA } \\
\text { CLASSIFICATION } \\
\text { - Entity extraction } \\
\text { - Entity hierarchies }\end{array}$ & $\begin{array}{l}\text { I. NAME MATCHING } \\
\text { - } \quad \text { Name blocking } \\
\text { - } \quad \text { Name matching }\end{array}$ & $\begin{array}{l}\text { I.PERSON DISAMBIGUATION } \\
\text { - } \quad \text { Name matching variables } \\
\text { - } \quad \text { Direct disambiguation } \\
\text { variables } \\
\text { - } \quad \text { Indirect disambiguation } \\
\text { variable } \\
\text { II.GLOBAL SCORE } \\
\text { - Weighted combination of } \\
\text { name matching, direct } \\
\text { disambiguation and indirect } \\
\text { disambiguation variables } \\
\text { III. CLUSTERS } \\
\text { - Consolidation of all pairs of } \\
\text { publication-author and } \\
\text { patent-inventor above a } \\
\text { certain threshold of their } \\
\text { global score }\end{array}$ & $\begin{array}{l}\text { I. MANUAL CHECKING OF POSITIVE } \\
\text { MATCHES } \\
\text { - With focus on potential } \\
\text { matches with low global score } \\
\text { and inconsistencies from } \\
\text { PATSTAT-PATSTAT and/or } \\
\text { SCOPUS-SCOPUS name } \\
\text { matching. } \\
\text { - } \quad \text { Reliance on information from } \\
\text { other sources for difficult cases } \\
\text { II. RECURSIVE VALIDATION OF THE } \\
\text { DISAMBIGUATION } \\
\text { - } \quad \text { Calculate new indirect } \\
\text { disambiguation variables based } \\
\text { on validated matches } \\
\text { - Recalculate global score and } \\
\text { revise clusters } \\
\text { Repeat until all potential false } \\
\text { positive matches are checked. }\end{array}$ \\
\hline
\end{tabular}

Source: Maraut, S. and Martinez, C. (2013), Identifying author-inventors from Spain: methods and a first insight into results. Working Paper Instituto de Políticas y Bienes Públicos, 2013/2, IPP-CCHS, CSIC, Madrid.

The final phase consists of checking manually the dubious matches provided by the 
algorithm in order to include those validated by reviewers into new automatic iterations. This enables the discarding of false positives resulting from the application of the previous phases of the methodology (machine-based) based on all available information from SCOPUS and PATSTAT as well as institutional and personal websites, which often required checking the original publications and patents available online.

We obtain very high precision and recall rates from testing the methodology against a benchmark dataset: close to 100\% precision and about $90 \%$ recall.

The final dataset is the result of matching 277,937 SCOPUS publications of Spanish authors with publication dates 2003-2008 and 16,741 EPO applications with Spanish inventors with filing dates 1978-2010. Applying the methodology just described, we identified 4,194 Spanish author-inventors affiliated to all types of institutions (academic and non-academic). ${ }^{28}$ They produced 33,801 SCOPUS publications between 2003 and 2008 and were listed as inventors in 4,426 EPO patent filings between 1978 and 2009.

For the purposes of the present study we use a subsample of the author-inventor pairs from the full database as we are interested in the production of scientific articles by academic author-inventors, defined as academic authors matched to inventors listed in patents filed before or in the publication year of their scientific articles.

\footnotetext{
${ }^{28}$ The final recursive validation phase for applying the methodology to the full dataset required the careful revision of around 30,000 author-inventor pairs.
} 